Originalartikkel

\title{
Frekvens av rettslig obduksjon etter dødsfall i veitrafikkulykker
}

\begin{abstract}
Sammendrag
Bakgrunn. I 2007 døde 224 personer i veitrafikkulykker i Norge. Etter påtaleinstruksen bør politiet begjære rettslig obduksjon ved slike dødsfall. Det skjer i varierende grad. Vi ønsket å kartlegge politiets begjæringspraksis ved slike dødsfall i Nord-Trøndelag og Sør-Trøndelag.
\end{abstract}

\begin{abstract}
Materiale og metode. For perioden 1996-2005 ble data fra rettslige obduksjoner av døde ved veitrafikkulykker i Nord-Trøndelag og Sør-Trøndelag utført ved Avdeling for patologi og medisinsk genetikk ved St. Olavs hospital sammenliknet med registrerte data for de tilsvarende dødsfallene i dødsårsaksregisteret i Statistisk sentralbyrå.
\end{abstract}

Resultater. I perioden døde 249 personer i veitrafikkulykker i de to fylkene. 157 (63\%) ble rettslig obdusert. Den rettslige obduksjonsfrekvensen falt fra $69 \%$ i første femårsperiode til $57 \%$ $i$ den andre. Størst var nedgangen i Nord-Trøndelag der frekvensen falt fra $62 \%$ til $38 \%$. Førere av motoriserte kjøretøy ble i større grad obdusert enn andre trafikanter, mens døde ved motorsykkelulykker i mindre grad ble obdusert enn omkomne ved personbilulykker og andre typer veitrafikkulykker.

Fortolkning. Reduksjon i obduksjonsfrekvensen og ulikheter i begjæringspraksis mellom politidistriktene kan være begrunnet i økonomiske forhold, ulik oppfatning av betydning av rettslig obduksjon eller ulik tolking av påtaleinstruksen. Det er ukjent om det var viktige forskjeller mellom omkomne som ble rettslig obdusert og dem som ikke ble obdusert.
Artikkelen er basert på førsteforfatters hovedoppgave ved Det medisinske fakultet, Norges teknisk-naturvitenskapelige universitet (1)

\section{Marit Igeltjørn}

Det medisinske fakultet

Norges teknisk-naturvitenskapelige universitet

\section{Ivar Skjåk Nordrum}

ivar.nordrum@ntnu.no

Institutt for laboratoriemedisin,

barne- og kvinnesykdommer

Det medisinske fakultet

Norges teknisk-naturvitenskapelige universitet Olav Kyrres gate 9

7489 Trondheim

og

Avdeling for patologi og medisinsk genetikk

St. Olavs hospital

I 2007 døde 224 personer i veitrafikkulykker i landet. I løpet av fem år hadde antall døde sunket fra 293 dødsfall i 2003 (2). Om lag $40 \%$ dør i møteulykker og om lag $30 \%$ i utforkjøringer. Andelen dødelige møteulykker har vært nokså stabil de siste årene, mens antall dødsfall etter utforkjøring har gått ned. Nesten halvparten av de omkomne er bilførere (3). Ved et stort antall av dødsulykkene er flere personer innblandet.

Ved alvorlige veitrafikkulykker vil politiet alltid komme til ulykkesstedet. Ved dødsfall skal politiet etter straffeprosessloven beslutte om de skal begjære sakkyndig likundersøkelse (4). Slik undersøkelse er i praksis obduksjon. Politiet skal ifølge påtaleinstruksen påse at sakkyndig likundersøkelse foretas når det er mistanke om at døden er forårsaket av en straffbar handling, og de bør i alminnelighet sørge for slik undersøkelse når dødsårsaken er uviss og antas å kunne skyldes et ulykkestilfelle (5).

En sakkyndig likundersøkelse (rettslig obduksjon) vil kartlegge og dokumentere ytre og indre skader, eventuelle sykdommer og forekomst av alkoholer, medikamenter og andre substanser i kroppsvæsker. Resultatene fra en rettslig obduksjon bidrar til å avklare årsakene til en ulykke, stadfester dødsårsaken og kan ha betydning for forsikringsoppgjør og straffeforfølgelse.

Ifølge Statistisk sentralbyrå er obduksjon i $41 \%$ av alle voldsomme dødsfall grunnlaget for dataene i dødsårsaksstatistikken (6). Voldsomme dødsfall, eller ikke-naturlige dødsfall, er dødsfall ved ulykker, selvmord og drap. Vi har begrenset systematisk kunnskap om hvor ofte det utføres rettslige obduksjon av omkomne i veitrafikkulykker, i hvilken grad dette har endret seg over tid og om det er forskjeller mellom politidistriktene.

En studie fra Troms og Finnmark viste at det var en betydelig forskjell mellom de seks politidistriktene i fylkene i begjæring av rettslig obduksjon ved voldsomme dødsfall i perioden $1988-92$ og at $58 \%$ av alle omkomne i veitrafikkulykker i samme periode ble rettslig obdusert (7). Det er betydelige forskjeller mellom de nordiske landene. I Finland ble hele $98 \%$ av alle dødsfall ved veitrafikkulykker rettslig obdusert i årene 2000-03 (8), mens denne frekvensen er ca. 20\% i Danmark (S.T. Larsen, foredrag ved 17. nordiske konferanse i rettsmedisin, Bergen 2009).

Det er en erfaring blant rettspatologer at begjæring av rettslig obduksjon praktiseres forskjellig i de ulike politidistriktene i landet. Noen politidistrikter begjærer nesten alltid obduksjon ved dødsfall ved veitrafikkulykker, andre politidistrikter gjør dette i mindre grad.

Målet med denne studien var å kartlegge hvor ofte politiet begjærte rettslig obduksjon ved dødsfall ved veitrafikkulykker i NordTrøndelag og Sør-Trøndelag i tiårsperioden 1996-2005.

\section{Materiale og metode}

De rettslige obduksjonsrapportene ved Avdeling for patologi og medisinsk genetikk ved St. Olavs hospital i perioden 1996-2005 ble gjennomgått. Dødsfall i forbindelse med veitrafikkulykke med dødssted i Nord-Trøndelag og Sør-Trøndelag ble identifisert. Avdelingen utfører alle rettslige obduksjoner av døde i de to fylkene. Følgende registrerte data ble anvendt i denne studien: dødsår, ulykkessted (fylke), dødssted (fylke), rekvirerende politidistrikt, alder, kjønn, type kjøretøy (personbil/motorsykkel/annet), trafikantgruppe (fører/ikke-fører), aleneulykke (ja/nei), oppgitte sykdommer, sykdommer påvist med betydning for døden, påviste skader og resultat av blodprøve samt underliggende og medvirkende dødsårsak (punkt Ic og II på dødsmeldingen).

\section{Hovedbudskap}

- Rettslig obduksjon er viktig i etterforskning av dødsfall ved veitrafikkulykker

- Obduksjonsfrekvensen av døde ved veitrafikkulykker er lav, fallende og varierer med politidistrikt

- Dagens obduksjonsfrekvens er neppe i samsvar med påtaleinstruksen

- Det bør vurderes om alle døde etter veitrafikkulykker bør bli rettslig obdusert 
Data fra dødsårsaksregisteret i Statistisk sentralbyrå fra samme periode ble bestilt. Inklusjonskriteriene var dødsfall i perioden 1996-2005 etter veitrafikkulykker med dødssted i Nord-Trøndelag og Sør-Trøndelag. Dataene skulle være stratifisert etter dødsår (1996-2000/2001-05), kjønn, alder (<30 år, 30-59 år, > 59 år), type kjøretøy og trafikantgruppe.

Stratifisering av data for beregning av obduksjonsfrekvenser ble i stor grad definert av de variablene som er anført i dødsårsaksregisteret. For eksempel registreres det ikke om det er en aleneulykke eller ikke. Dataene i denne studien er for øvrig basert på dødsstedskommune, mens standardtabellene fra dødsårsaksregisteret er basert på bostedskommune etter folkeregisteret uavhengig av i hvilken kommune eller i hvilket land døden inntrådte.

Veitrafikkulykker i dødsårsaksregisteret er ulykker som skjer på offentlig eller privat vei, der det er åpent for alminnelig ferdsel og der minst ett motorisert kjøretøy er involvert (9). Den døde kan slik for eksempel være fotgjenger påkjørt av bil. Ulykke i veitrafikken der selvdrap eller sykdom konkluderes som årsak til ulykken, kategoriseres ikke som veitrafikkulykke i dødsårsaksregisteret, og ble derfor ikke inkludert i datasettene. Dødsårsaken (punkt Ic i dødsmeldingen: underliggende dødsårsak) ved slike hendelser blir registrert som selvdrap eller den aktuelle sykdom og ikke som veitrafikkulykke. Blant de obduserte i tiårsperioden gjaldt dette et selvdrap og tre naturlige dødsfall.

Politidistriktene følger fylkesgrensene.
Namdal og Inntrøndelag politidistrikt i NordTrøndelag og Trondheim og Uttrøndelag politidistrikt i Sør-Trøndelag ble 1. januar 2002 slått sammen til henholdsvis Nord-Trøndelag politidistrikt og Sør-Trøndelag politidistrikt.

Blant de obduserte var ulykkessted og dødssted ikke alltid innen samme politidistrikt. I fem tilfeller skjedde ulykken i NordTrøndelag, mens døden inntrådte på St. Olavs hospital i Sør-Trøndelag. I 11 tilfeller skjedde ulykken i Helgeland, Møre og Romsdal eller Østerdal politidistrikt, mens døden inntrådte på St. Olavs hospital. I disse tilfellene var det politidistriktet på ulykkesstedet som begjærte obduksjon. De 11 tilfellene der ulykken skjedde utenfor trøndelagsfylkene, ble ikke inkludert videre. Datasettet fra Statistisk sentralbyrå ble justert fra dødssted til ulykkessted ved at Nord-Trøndelag fikk et tillegg på de nevnte fem tilfellene, mens Sør-Trøndelag fikk et fratrekk på til sammen 16 tilfeller.

Ved innsamling av data fra obduksjonsrapportene ble det brukt et registreringsskjema. Dataene ble deretter overført til og behandlet i programmet SPSS.

Studien er godkjent av regional komité for medisinsk forskningsetikk Midt-Norge og Riksadvokaten.

\section{Resultater}

I tiårsperioden 1996-2005 ble det identifisert 157 rettslige obduksjoner som tilfredsstilte inklusjonskriteriene. Et likskue av et barn etter en trafikkulykke ble ikke inkludert.

Tabell 1 viser at frekvensen av rettslige obduksjoner av døde etter veitrafikkulykker i begge fylker samlet sank fra $69 \%$ i første femårsperiode til $57 \%$ i den andre. Det var en nedgang i begge fylker. Størst var nedgangen i Nord-Trøndelag, som hadde en lavere frekvens av rettslige obduksjoner enn SørTrøndelag i begge femårsperiodene. I begge fylker ble førere av motorkjøretøy hyppigere obdusert enn dem som ikke var førere eller som hadde ukjent trafikantstatus. Dødsfall ved motorsykkelulykker ble i mindre grad obdusert enn dødsfall ved personbilulykke og andre type ulykker, spesielt i Nørd-Trøndelag.

I over $70 \%$ av tilfellene var to eller flere trafikanter involvert i ulykken.

I 23 dødsfall (15\%) ble sykdom vurdert som mulig medvirkende dødsårsak. I de fleste tilfellene dreide dette seg om koronar aterosklerose med følgetilstander, unntatt ferskt infarkt. I 14 av 23 tilfeller var den omkomne fører, og 16 var over 59 år.

Det ble tatt blodprøve i forbindelse med 121 av obduksjonene. Hos 37 obduserte (31\%) var etanolkonsentrasjonen i blod $\geq 0,2$ promille, og 15 av disse hadde over 2,0 i promille. Henholdsvis 22 og ni var førere. Det ble påvist medikamenter eller illegale stoffer hos 30 av 121 tilfeller (25\%). I 14 av tilfellene kan dette ha hatt betydning for handlingsevnen, og fem av disse hadde i tillegg over 0,2 promille etanol i blod.

\section{Diskusjon}

I denne studien av frekvenser av rettslig obduksjon $\mathrm{i}$ en tiårsperiode er det påvist

Tabell 1 Antall dødsfall og rettslig obduserte ved veitrafikkulykker i Midt-Norge 1996-2005 etter trafikantstatus, type kjøretøy, alder, kjønn og tidsperiode

\section{Sør-Trøndelag}

Døde Obduserte Obduksjonsfrekvens

$\begin{array}{ccc}\text { Døde } & \text { Obduserte } & \text { Obduksjonsf } \\ (\mathrm{n}) & (\mathrm{n}) & (\%)\end{array}$

Trafikant

Fører

Ikke-fører/ukjent

91

Kjøretøy

Motorsykkel

Personbil

Andre 1/ukjent

Alder

< 30 år

30-59 år

> 59 år

Kjønn

Menn

Kvinner

Tidsperiode

1996-2000

2001-2005

Samlet

73

44

4

61

42

49

68

54

46

41

44

32

115

53

86

89

79

168

80

57

47

69

86

60

81

70

75

58

72

67

70

117

$\begin{array}{lll}45 & 23\end{array}$

36

17

Nord-Trøndelag

Døde Obduserte Obduksjonsfrekvens

(n)

8

1

55

18

29

10

38

20

23

21

7

12

$60 \quad 27$

21

13

39

42

81

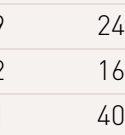

24
16

40

3

Andre typer kjøretøy, fotgjengere og syklister

$[\%]$

51

47

Samlet

Døde Obduserte Obduksjonsfrekvens

(n) (n) $\quad(\%)$

$\begin{array}{lll}136 & 96 & 71\end{array}$

113

61

54

13

53

56

38

15

39

144

67

90

52

63

78

55
35
52

106

74

69

62

51

44

69

64

45

175

113

65

62

74

44

59

62

128

121

249

69

157

69

57

49

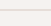

\begin{tabular}{l}
1 \\
4 \\
39 \\
3 \\
8 \\
\hline 8 \\
69 \\
64 \\
\hline 5 \\
59 \\
69 \\
7 \\
\hline 3
\end{tabular}


fallende obduksjonsfrekvens over tid og tydelige forskjeller mellom to politidistrikter. Det kan diskuteres om dette er i samsvar med påtaleinstruksen.

Flere førere enn andre ble obdusert. Dette er logisk, siden disse ofte har stor betydning for at en veitrafikkulykke oppstår. At så få omkomne i motorsykkelulykker ble obdusert, spesielt i Nord-Trøndelag, kan synes noe påfallende. En forklaring kan være at omstendighetene oppfattes som oversiktlige, siden dette er typisk høyenergetiske ulykker med én person involvert.

Politidistriktene følger fylkesgrensene. I 2002 ble de to politidistriktene i hvert av fylkene slått sammen til ett. Det er uklart om dette har påvirket begjæringspraksisen. Etterforskningsutgifter, som kostnader forbundet med rettslig obduksjon, dekkes av det enkelte politidistrikt. Strammere budsjett kan forklare nedgangen i obduksjonsfrekvens, men kanskje ikke alene forskjellene mellom politidistriktene. Transportkostnader for å frakte den døde til rettslig obduksjon har trolig en viss betydning. Det er neppe sannsynlig at karakteristika ved ulykkene kan forklare forskjellene i begjæringspraksis.

Andelen personer med alkohol, medikamenter eller andre stoffer i blodet var i samme størrelsesorden som påvist $\mathrm{i}$ andre norske studier, men studiene er ikke direkte sammenliknbare (10-12). Påvirkning av rusmidler er en viktig årsaksfaktor til mange veitrafikkulykker, og ruspåvirkning bør i slike tilfeller registreres som medvirkende dødsårsak. Slike forhold underregistreres i dødsårsaksregisteret. En studie har vist at alkoholpåvirkning (definert som $\geq 0,5$ promille) ikke ble ført som medvirkende dødsårsak og derfor ikke registrert i dødsårsaksregisteret i ca. $60 \%$ av veitrafikkulykkene med slike funn (11). Det er ukjent i hvilken grad det tas blodprøve av omkomne som ikke obduseres.

De tilfellene der veitrafikkulykken ble utløst av sykdom, ble ikke inkludert i denne studien. Underliggende dødsårsak i slike tilfeller er sykdommen, og dette blir dødsårsaken i dødsårsaksregisteret, ikke veitrafikkulykken. Om sykdom har hatt betydning for en ulykke, vil være uavklart på skadestedet. Slike forhold avklares først ved obduksjon. En studie av 230 bilførere som døde i veitrafikken, viste at $12 \%$ av disse døde av sykdom (12).

Det primære datagrunnlaget i dødsårsaksregisteret er dødsmeldingene fra lege. I de tilfellene det foretas obduksjon, skal resultatet meldes dødsårsaksregisteret (13). De vil normalt korrigere tidligere opplysninger om dødsårsaken dersom det er diskrepans. Datasettet fra Statistisk sentralbyrå baserer seg derfor på to ulike diagnosegrunnlag: de obduserte og de ikke-obduserte. Det er rimelig å anta at det er et lite antall blant de ikke-obduserte som ved en obduksjon ville bli kategorisert som sykdomstilfelle eller selvdrap.

De rettslig obduserte i denne studien representerte et utvalg av dødsfallene ved vei- trafikkulykkene. Det er ukjent om det var viktige forskjeller mellom denne gruppen og den gruppen som ikke ble obdusert.

Formuleringene i påtaleinstruksen gir rom for tolking. Påtaleinstruksen forholder seg til dødsfall ved ulykker og ikke eksplisitt til forskjellige kategorier som fallulykker og veitrafikkulykker.

Den store kategorien dødsfall ved fallulykker skiller seg klart fra alle andre ulykkeskategorier. Flertallet av dødsfall ved fall er de gamle beinskjøre som faller på flatt underlag eller i trapp, brekker lårhalsen og som etter et sykeleie typisk dør av lungeemboli eller lungebetennelse. Det var kanskje ikke denne type dødsfall som var viktig ved utformingen av instruksen. Begjæringspraksis reflekterer også det. I perioden 1988-92 ble kun 4,5 \% av dem over 59 år som døde i en fallulykke, rettslig obdusert i Troms og Finnmark (7). Det er ikke holdepunkter for at dette er annerledes i dag, og praksis er antakeligvis fornuftig.

I motsetning til fallulykker involverer dødsfall ved veitrafikkulykker ofte mer enn én person. Konsekvensene for de involverte kan være omfattende. Rettslig obduksjon er en viktig del av etterforskningen og gir svar på sykdomsforhold og eventuell påvirkning av medikamenter eller andre stoffer som kan ha hatt betydning for hendelsesforløpet og utfallet. De ytre og indre skader blir kartlagt. Dette bidrar til å besvare ulike spørsmål som om sikkerhetsbelte ble brukt, grad av energi i ulykken og andre forhold i hendelsesforløpet. Adekvat kartlegging av hendelsesforløp og årsaksforhold er viktig for de pårørende, for forsikringsutbetalinger og for vurdering av eventuell straffeforfølgelse.

\section{Konklusjon}

Denne studien viste at det var en reduksjon i frekvensen av rettslig obduksjon i Nord- og Sør-Trøndelag i perioden 1996-2005 og at det var store forskjeller mellom politidistriktene. Ulikheter i begjæringspraksis kan være begrunnet i økonomiske forhold, ulik oppfatning av betydning av rettslig obduksjon og ulik tolking av påtaleinstruksen. Obduksjonsfrekvensen var samlet lav og fallende. Beslutning om rettslig obduksjon må tas kort tid etter en ulykke på et tidspunkt neppe alle omstendigheter omkring ulykken er avklart. Derfor bør begjæringspraksisen være liberal. Det bør vurderes om det ikke er hensiktsmessig å obdusere alle som omkommer i veitrafikkulykker.

Oppgitte interessekonflikter: Ivar Skjåk Nordrum er rettspatolog. Det utbetales honorar for hver rettslig obduksjon som utføres.

Nord-Trøndelag og Sør-Trøndelag politidistrikt er orientert om resultatet av denne studien.
Litteratur

1. Igeltjørn M. Dødsfall ved veitrafikkulykker i MidtNorge 1996-2005. Hovedoppgave. Trondheim: Det medisinske fakultet, NTNU, 2008.

2. Statistikkbanken. Tabell 03507. Dødsfall av trafikkulykker, etter kjønn, alder og trafikantgruppe. www.ssb.no/statistikkbanken (22.6.2009)

3. Statistikkbanken. Tabell 06753: Veitrafikkulykker med personskade, endelig tall 2007. www.ssb.no/ statistikkbanken (22.6.2009).

4. Lov om rettergangsmåten i straffesaker (straffeprosessloven). www.lovdata.no/all/nl-19810522 025.html (3.6.2009).

5. Forskrift om ordningen av påtalemyndigheten (påtaleinstruksen). www.lovdata.no/cgi-wift/ Idles?doc=/sf/sf/sf-19850628-1679.html (3.6.2009).

6. Grunnlagsmaterialet for koding av underliggende dødsårsak. 2006. Oslo: Statistisk sentralbyrå 2008. www.ssb.no/emner/03/01/10/dodsarsak/ arkiv/tab-2008-06-27-21.html (22.6.2009).

7. Nordrum I, Eide TJ, Jørgensen L. Forensic pathology in Northern Norway. Requested medicolegal autopsies in the counties of Finnmark and Troms 1973-1992. APMIS 1996; 104: 465-74.

8. Lunetta P, Lounamaa A, Sihvonen S. Surveillance of injury-related deaths: medicolegal autopsy rates and trends in Finland. Inj Prev 2007; 13 $282-4$.

9. Statistisk sentralbyrå. Variabeldefinisjon veitrafikkulykker. www.ssb.no/metadata/ conceptvariable/vardok/1833/nb (22.6.2009)

10. Breivig T, Arnestad M, Mørland J et al. Hvilken betydning har sykdom, ruspåvirkning og selvmord ved dødsfall blant bilførere? Tidsskr Nor Lægeforen 2004; 124: 916-9.

11. Nordrum I, Eide TJ, Jørgensen L. Alcohol in a series of medico-legally autopsied deaths in northern Norway 1973-1992. Forensic Sci Int 2000; 110: 127-37.

12. Alvestad M, Haugen OA. Dødsfall bak rattet Tidsskr Nor Lægeforen 1999; 119: 966-8.

13. Forskrift om obduksjon m.m. www.lovdata.no/for/ sf/ho/xo-20040319-0542.html (3.6.2009).

Manuskriptet ble mottatt 18.9. 2008 og godkjent 30.7. 2009. Medisinsk redaktør Siri Lunde. 